\title{
Realkompetansevurdering i norske kommuner
}

(Validation of prior learning in Norwegian municipalities)

\author{
Erik Døving \& Anita E. Tobiassen \\ Handelshøyskolen ved OsloMet - Storbyuniversitetet, Norge \\ (erikdo@oslomet.no)
}

\begin{abstract}
Workers in Norway can get skills acquired through informal and incidental learning validated in a formal process. The educational authorities issue a certificate stating that the worker's skill level is equivalent to a certain level of vocational education. This way, the worker can more easily obtain a vocational degree. We describe and discuss how Norwegian employers facilitate validation for unskilled employees within municipal nursing and care, and we discuss how municipal employees can get their skills formally recognised. Results are based on qualitative interviews and written surveys in seven municipalities. Validation is useful for workers mostly as a stepping-stone to complete a vocational education, while from the municipal employers' perspective validation as such is of limited use. Only every fourth worker knows about the national system for validation of skills, and workers that can benefit most know the least about the system. The results presented here show that the employer and co-workers are the most important source of information, while trade unions are less active in providing such information. Our results further imply that information and initiatives should be targeted at immigrants in particular. In addition, counties responsible for vocational education vary in how they implement the validation system.
\end{abstract}

Keywords: validation of prior learning, vocational education, municipalities, Norway, nursing and care

NJVET, Vol. 10, No. 3, 1-16 Magazine article doi: 10.3384/njvet.2242-458X.201031 


\section{Innledning}

I denne artikkelen beskriver vi ordningen med realkompetansevurdering i Norge. Realkompetanse omfatter formell kompetanse opparbeidet i utdanningssystemet og uformell kompetanse utviklet gjennom erfaring. Realkompetansevurdering kan brukes både for å gjøre veien til kvalifikasjoner på videregående skoles nivå (ikke minst fagbrev) kortere og som grunnlag for opptak til høyere utdanning. Vi fokuserer på realkompetansevurdering med sikte på fagbrev innenfor pleie og omsorg i kommunal sektor. Innenfor dette fagområdet er det særlig mange ufaglærte samtidig som kommunene står fremfor tiltagende knapphet på kvalifisert arbeidskraft. I pleie- og omsorgssektoren er det en stor andel innvandrere og mange innvandrere tar videregående yrkesutdanning i voksen alder innenfor helsefag. Hver tredje voksen som tar videregående opplæring velger helsefag (Vox, 2013). Artikkelen bygger hovedsakelig på intervjuer med en rekke ledere og tillitsvalgte i syv kommuner og en spørreundersøkelse blant medarbeidere i de samme kommunene. Den empiriske undersøkelsen ble avsluttet i 2008, men ordningen med realkompetansevurderingen består (Utdanningsdirektoratet, 2014). Andelen innvandrere i den kommunale pleie- og omsorgssektoren har $ø$ kt fra 11 \% i 2009 til $17 \%$ i 2017, i Oslo er andelen 44 \% (SSB, 2018). Dette tilsier at problemstillingene vi tar opp har blitt stadig mer aktuell årene.

Realkompetansevurdering innebærer at uformell kompetanse opparbeidet gjennom erfaring blir dokumentert og anerkjent på linje med formell kompetanse i form av for eksempel vitnemål fra utdanningsinstitusjoner. I Norge har alle voksne over 25 år uten fullført videregående skole rett til realkompetansevurdering (opplæringsloven § 4A-3). Retten gjelder både for de som ønsker å gjennomføre videregående opplæring og de som kun ønsker å få dokumentert sin kompetanse. Voksne med slik rett skal vurderes opp mot en læreplan i videregående opplæring (Hult \& Andersson, 2008). Etter gjennomført vurdering får vedkommende utstedt et kompetansebevis eller vitnemål. Av kompetansebeviset skal det fremgå hvilke deler av læreplanen som er godkjent på bakgrunn av realkompetansevurderingen.

En realkompetansevurdering kan for mange gjøre veien til fagbrev eller studiekompetanse kortere ved at den enkelte kan få godkjenning av hele, eller deler av et fag i den videregående opplæringen (Røstad \& Solli, 2006). Et sentralt spørsmål blir dermed hvordan realkompetansevurdering fungerer i samspill mellom arbeidstaker, myndigheter og arbeidsplass. Realkompetansevurdering kan stimulere til kompetanseheving for voksne, ufaglærte arbeidstakere noe som kan være gunstig både for sysselsettingen og for kommunenes tilgang til kvalifisert arbeidskraft (Albrecht, Berg \& Vroman, 2005; Falch, 2011; Hermansen, 2011; Høst, Arnesen, Næss \& Aamodt, 2009). 


\section{Realkompetansevurdering i Norge}

\section{Rettigheter}

Realkompetansevurdering var ett av flere tiltak under den norske Kompetansereformen (Stortingsmelding nr. 42 1997-98). Alle voksne over 25 år uten fullført videregående skole har lovfestet rett til å få realkompetansevurdert sin kompetanse. Denne retten ble innført i 2003. Retten gjelder både for de som ønsker videregående opplæring, og for de som kun ønsker å få dokumentert sin kompetanse. Voksne uten rett til videregående opplæring og som ikke er henvist av annen offentlig instans (som for eksempel NAV), kan etter søknad til fylkeskommunen (som har ansvaret for videregående opplæring) få sin realkompetanse vurdert. Retten er lovregulert og gjelder også for personer som ikke er i et arbeidsforhold. Opplæringsloven omfatter alle som har fullført grunnskoleutdanningen, men som ikke tidligere har fullført videregående opplæring. Realkompetansevurdering som grunnlag for opptak i videregående skole går vi ikke nærmere inn på her. I arbeidslivet er det ingen rett til realkompetansevurdering, men kompetanseutvikling er nedfelt i Hovedtariffavtalen for kommunesektoren.

I praksis betyr realkompetansevurdering for voksne med lite utdanning at det vurderes i hvilken grad personens kompetanse opparbeidet gjennom erfaring og praksis oppfyller kravene til bestemte program eller fag i videregående skole innenfor pleie og omsorg vil dette gjelde utdanning som helsefagarbeider. For videregående opplæring skal nasjonale læreplaner benyttes ved vurdering av realkompetanse. Realkompetansevurderingen resulterer i et kompetansebevis og dette blir på samme måte som et vitnemål individets eiendom. Ut over å være et redskap for å avdekke kompetanse som finnes, er hensikten med realkompetansevurdering at den enkelte voksne skal få dokumentere sin kompetanse og eventuelt supplere denne med videre utdanning for å oppnå kvalifikasjoner som er etterspurt (Haugerud, Røstad \& Stubbe, 2004).

\section{Gjennomføring}

I Norge har fylkeskommunene ansvar for videregående opplæring og de har plikt til å sørge for videregående opplæring også for voksne. Fylkeskommunene har også ansvar for å gjennomføre realkompetansevurdering og å utferdige kompetansebevis på grunnlag av denne vurderingen. De fleste fylkeskommunene organiserer arbeidet gjennom ett eller flere sentre, eller har lokalisert arbeidet til videregående skoler. Når vurdering skal skje i henhold til læreplaner, benyttes fagpersoner i det aktuelle faget.

Det er forholdet mellom den voksnes realkompetanse og kompetansemålene i Læreplanverket som avgjør hva den voksne trenger av videregående opplæring for å oppnå den ønskede sluttkompetansen. Dersom den voksne bare får godkjent deler av et fag, skal det fremgå hvilke deler av faget som er godkjent. Det 
vil være viktig for å kunne vurdere hvilken opplæring den voksne har behov for og krav på for å kunne bestå det aktuelle faget (Utdanningsdirektoratet, 2008).

Første trinn i den samlede vurderingsprosessen er kartlegging som dokumenterer eller beskriver den enkeltes kompetanse, dette kan være attester, kursbevis eller annen dokumentert læringsaktivitet. Kartleggingen kan også beskrive kompetanse opparbeidet på en arbeidsplass. Andre trinn i prosessen er å vurdere den kartlagte kompetansen mot gitte kriterier. I det offentlige utdanningssystemet er læringsmålene i den aktuelle utdanningen vurderingskriterium. En faglærer eller annen fagperson vurderer realkompetansen ved bruk av metoder som samtale, vurdering av dokumentasjon eller vurdering av praktisk arbeid. I siste trinn blir det utarbeidet dokumentasjon fra vurderingen. Kartlegging og vurdering av realkompetanse skal oppsummeres skriftlig. Dette vil være viktig for etterprøvbarhet og den voksnes rettssikkerhet. Kompetansebeviset skal si noe om hvilken formell og uformell realkompetanse den voksne har.

Det blir anbefalt at realkompetansevurderingen skal skje med den metoden som er best egnet for den enkelte. De tre aktuelle metodene for realkompetansevurdering er (Vox, 2006):

- Dialogbasert metode som er en samtale mellom kandidaten og en fagperson. Fagpersonen skal ta utgangspunkt i de kunnskaper og erfaringer den voksne arbeidstakeren har. Denne metoden krever individuell tilrettelegging og et personlig møte.

- Vurdering på bakgrunn av innsendt dokumentasjon i form av et kartleggingsskjema sammen med vitnemål og attester. Metoden forutsetter ikke personlig oppmøte. Metoden er effektiv for arbeidstakere med god skriftlig dokumentasjon.

- Yrkesprøving er en vurderingsmetode tilpasset voksne arbeidstakere som mangler dokumentasjon av utdanning og/eller arbeidserfaring. Yrkesprøving består av et intervju der den voksnes bakgrunn, utdanning, arbeidserfaring, språkferdigheter og målsetting blir kartlagt. Deretter blir det gjennomført et fagintervju og en praktisk prøve.

\section{Fylkeskommunens praksis}

Fylkeskommunene er gitt stor frihet til å prøve ut ulike prosedyrer, organisering, modeller og verktøy knyttet både til realkompetansevurdering og voksnes rett til videregående opplæring (Vox, 2007). Fylkeskommunene har noe ulik praksis for realkompetansevurdering - det er ulike oppfatninger om hvordan lovverket skal forstås og praktiseres (Vox, 2011). Organiseringen av arbeidet er ulik både med hensyn til hvor den skjer, hvilke metoder og vurderingsverktøy som brukes samt hvilke samarbeidspartnere som involveres (Engesbak mfl., 2003; Røstad \& Storli, 2006). Ytterpunktene spenner fra en sterkt sentralisert struktur til at arbeidet inngår som en liten ressurs på en videregående skole. Brukerne har hatt noen 
vansker med å finne frem fordi navnene på kontoret eller senteret med ansvar for realkompetansevurdering ikke er selvforklarende og dessuten varierer mellom fylkeskommunene (Vox, 2007).

Røstad og Storli (2006) fant i sin undersøkelse at realkompetansevurderingen ofte ble gjennomført i form av en samtale, og at det ble lagt mindre vekt på skriftlige dokumenter. I et tilfelle skjedde vurderingen i hovedsak på grunnlag av innsendt, skriftlig dokumentasjon. Når kandidatene mangler skriftlig dokumentasjon, stiller dette store krav til at fagkonsulentene får fram kompetansen $i$ en vurderingssamtale. Mange av fagkonsulentene la stor vekt på teori, noe som betyr at arbeidspraksis ikke godkjennes fullt ut som likeverdig med teoretisk opplæring. Kandidater som skal få realkompetansevurdering vet ofte ikke hva de faktisk kan fordi de mangler de teoretiske begrepene til å sette ord på sin erfaringsbaserte kompetanse. Dette kan være en utfordring når de møter fagkonsulenter som legger stor vekt på teori.

Fylkeskommunene brukte til dels ulike metoder med en kombinasjon av vurderingsmetoder i realkompetansearbeidet, både skriftlig dokumentasjon og samtale/intervju (Haugerud mfl., 2004). Det var særlig store forskjeller med hensyn til hvor omfattende prosedyren med intervju/samtale i verdsettingsdelen er, og vektleggingen på veiledning og rådgivning. For eksempel bruker en av fylkeskommunene to metoder: (a) samtalebasert vurdering hvor en faglærer går gjennom læreplanen i det aktuelle faget sammen med kandidaten for å finne ut hva vedkommende kan i forhold til teorikravet, og (b) yrkesprøving. I en annen fylkeskommune skjer vurderingen på bakgrunn av en samtale ved den skolen som har de fagene en ønsker opplæring i. Vurderingen omfatter (a) tidligere utdanning (vitnemål og attester og lignende); (b) udokumentert kompetanse kartlagt gjennom egenvurdering og samtale med faglærer (dialogbasert metode); og (c) yrkesprøving. Vurderingen utføres til dels av de samme faglærerne som har ansvar for undervisningen på området.

\section{Bruk av realkompetansevurdering}

Blant voksne som tok videregående opplæring i 2006 er helse- og sosialfag klart det vanligste, av disse er godt over halvparten realkompetansevurdert og $84 \%$ av disse igjen har grunnlag for avkortet opplæring (Vox, 2007). De siste årene har omkring 2400 personer blitt realkompetansevurdert årlig, dette utgjorde $12 \%$ av voksne deltakere i videregående opplæring (Vox, 2012, 2013). I løpet av skoleåret 2006-2007 gjennomgikk 6800 realkompetansevurdering, tallet har deretter vært noe fallende (Vox, 2011). En forklaring på dette fallet kan være at de første par årene var utslag av oppdemmet behov slik at omfanget de etterfølgende årene kanskje er nede på et normalt nivå.

I en spørreundersøkelse i 2003 var nær halvparten av befolkningen ikke interessert i realkompetansevurdering (Engesbak mfl., 2003). Interessen synker med alder, og dette gjelder spesielt for menn. Interessen hos kvinner synker med 
økende utdanningsnivå. Resultatene tyder på at kvinner som er lavt utdannet er en gruppe som vil være motivert for realkompetansevurdering og eventuelt kompetanseheving. I 2006 kjente $26 \%$ av arbeidstakerne til ordningen med vurdering av realkompetanse, mens hele $74 \%$ av arbeidstakerne kjente $i k k e$ til ordningen (Vox, 2006). Personer med lite utdanning har minst kjennskap til rett til opplæring på grunnskole- eller videregående nivå (Engesbak mfl., 2003). Paradoksalt nok er det personer med denne retten som har minst kjennskap til ordningen, og få vet hvor de kan henvende seg for å få sin realkompetanse vurdert. 56 \% er interessert i å få dokumentert sin realkompetanse når de får informasjon om ordningen (Vox-barometeret, våren 2004).

Arbeidsgiver kan være en viktig kilde for ansatte om informasjon om mulighetene til realkompetansevurdering, selv om det også hos arbeidsgiveren (kommunen) viser seg å være til dels mangelfull kjennskap til ordningen (Helgesen, Stigen \& Tjerbo, 2009). For en arbeidsgiver kan det ut fra et strategisk synspunkt være interessant å få dokumentert viktig kompetanse som ansatte besitter (Nordhaug, Døving \& Nordhaug, 2004). Uformell kompetanse er mer sammensatt og mindre tilgjengelig for kartlegging, mens formell kompetanse kan beskrives i form av klart definerte utdanninger, fag og grader. Erfaringsbakgrunnen representerer den uformelle kompetansen, og her bør man kartlegge både hvilke funksjoner og oppgaver en medarbeider har ivaretatt tidligere og utfører i dag.

Mens vurdering av realkompetanse gjerne har utgangspunkt i enkeltpersoners behov og ønsker, henger arbeidsgiverens tilrettelegging også sammen med virksomhetens behov og personalpolitikk. Kompetansekartlegging og vurdering av realkompetanse har fra et strategisk synspunkt begrenset verdi for kommunale arbeidsgivere om det ikke følges opp av andre tiltak for kompetanse- og karriereutvikling (Helgesen, Stigen \& Tjerbo, 2009). For de medarbeiderne som har lovfestet rett til å få vurdert sin kompetanse, kan en slik realkompetansevurdering være et første steg for videre kompetanse- og karriereutvikling. Den kommunale arbeidsgivers tilrettelegging for realkompetansevurdering kan dermed sees i sammenheng øvrig praksis på personal- og kompetanseområdet.

\section{Datagrunnlag}

I Norge har kommunene på laveste nivå (primærkommunene) ansvar for pleie og omsorg blant annet i form av alders- og sykehjem. Om lag halvparten av de ansatte $\mathrm{i}$ kommunene er innenfor helse- og sosialtjenester. I 2008 innhentet vi data fra i alt syv primærkommuner. Blant disse er det en storby, en stor forstadskommune, en stor landkommune og fire utkantkommuner. Kommunene representerer dermed ulike deler av landet og er forskjellige med hensyn til størrelse og til dels hvilke utfordringen de står overfor (tabell 1). Innenfor pleie og omsorg var det $25-40 \%$ ufaglærte da undersøkelsen ble gjort. For å styrke tilgangen på faglærte hjelpepleiere og omsorgsarbeidere legger myndighetene vekt på utvikling 
av ufaglærte som allerede er ansatt i kommunene (Sosial- og helsedirektoratet, 2006).

Tabell 1. Kommuner i undersøkelsen, nøkkeltall og respondenter.

\begin{tabular}{|l|r|r|r|r|r|r|}
\hline Kommune & $\begin{array}{r}\text { Folke- } \\
\text { tall }\end{array}$ & $\begin{array}{r}\text { \% inn- } \\
\text { vandrere }\end{array}$ & Årsverk & $\begin{array}{r}\text { Av disse } \\
\text { i helse/ } \\
\text { sosial }\end{array}$ & $\begin{array}{r}\text { \% ufaglærte } \\
\text { i pleie og } \\
\text { omsorg }\end{array}$ & $\begin{array}{r}\text { Respon- } \\
\text { denter }\end{array}$ \\
\hline Bergen & 250.000 & 9,6 & 11.600 & 6.300 & $30-40$ & 70 \\
\hline Bærum & 107.000 & 13,2 & 6.200 & 3.200 & 30 & 20 \\
\hline Bø & 3.000 & 4,3 & 250 & 150 & 32 & 0 \\
\hline Hadsel & 8.000 & 5,3 & 720 & 420 & 25 & 13 \\
\hline Kongsvinger & 17.300 & 8,5 & 972 & 510 & 25 & 27 \\
\hline Kvam & 8.300 & 4,3 & 780 & 380 & 37 & 22 \\
\hline Ringsaker & 32.000 & 4,1 & 1.839 & 960 & 35 & 61 \\
\hline
\end{tabular}

a Personer som selv har innvandret og personer født i Norge av foreldre født i utlandet.

$\mathrm{b}$ Ingen brukbare skjema mottatt.

Kilder: SSB, KS/PAI. Tall for et av tre siste år (før 2008).

Vi gjennomførte halvstrukturerte intervjuer og telefonintervjuer med nøkkelinformanter i den kommunale administrasjonen samt lokale fagforeningsledere. Gjennom intervjuene fikk vi en oversikt over hvordan de aktuelle kommunene arbeidet med realkompetansevurdering.

Spørreundersøkelsen var rettet mot målgruppen for realkompetansevurdering, både arbeidstakere som var aktuelle for vurdering og arbeidstakere som hadde gjennomført en slik vurdering. Respondentene sendte svarene anonymt direkte tilbake til oss. Tabell 1 viser antall svar for hver kommune. Ved gjennomgang av listen over ansatte viste det seg at mange falt utenfor målgruppen av ulike grunner, noe som betyr at målgruppen for realkompetansevurdering er noe mindre enn anslått ut fra totaltall for kommunene. I alt fikk vi inn 213 utfylte skjema, noen skjema var imidlertid ikke fullstendig utfylt slik at for enkelte tabeller er grunnlaget noe færre enn 213 . Vi delte ut i alt 828 skjema noe som gir en respons på $26 \%$. Respons på omkring $30 \%$ er vanlig for undersøkelser som dette. Utvalget er dominert av kvinner (86 \%) og det er større andel innvandrere enn i befolkningen generelt. Dette samsvarer med andelen kvinner og andelen innvandrere som tar helsefagutdanning på videregående skoles nivå (Vox, 2013). Om lag to tredeler arbeider deltid, og en tredel er midlertidig ansatt. Dette utvalget samsvarer også med de typiske deltakerne i realkompetansevurdering i Norge (Hult \& Andersson, 2008). Vi har derfor ikke noe grunn til å tro at svarprosenten har skapt noen vesentlige skjevheter i utvalget. 


\section{Realkompetansevurdering i kommunene}

\section{Kommunenes tilrettelegging for realkompetansevurdering}

Kommunene hadde i varierende grad oversikt over hvor stor andel av medarbeiderne som er ufaglærte, faglærte eller med høyere utdanning. Dette kan skyldes at kartlegging av all kompetanse, særlig realkompetanse, er et svært krevende arbeid. Realkompetansevurdering i seg selv syntes i liten grad å være relevant fra kommunenes synspunkt. Det kan være en av grunnene til at kommunen som arbeidsgiver gir lite eller ingen informasjon om mulighetene for realkompetansevurdering isolert sett. Unntaket er tillitsvalgte som i noen grad informerer om mulighetene for sine medlemmer. Dette betyr imidlertid ikke at kommunene er uinteressert i realkompetansevurdering. Tilrettelegging for realkompetansevurdering er noe som skjer i tilknytning til videreutdanning, og da spesielt i forbindelse med å gi ansatte muligheten til å ta en fagutdanning (fagbrev), slik at realkompetansevurdering vil være et ledd i dette arbeidet.

Kommunenes målsetting er at alle ansatte skal ha fagbrev, ikke minst innenfor pleie- og omsorg. Helse- og sosialsektoren er blant de bransjene som er mest opptatt av formell utdanning ved rekruttering av nye tilsatte (Hilleren mfl., 2004). Kommunene står overfor store utfordringer innenfor helse og omsorg, én av dem er raskere utskrivning av pasienter fra sykehus, noe som stiller større krav til kompetanse på sykehjemmene. Det er vanskelig for kommunene å rekruttere tilstrekkelig mange med fagbrev, dermed er en løsning å gi opplæring til nåværende medarbeidere (Meld. St. 13 (2011-2012)).

For eksempel opprettet en kommunene i vår undersøkelse i samarbeid med fylkeskommunen et systematiske opplegg for realkompetansevurdering og kompetanseutvikling ("fra ufaglært til faglært") både innenfor helse- og sosialfag og barne- og ungdomsarbeiderfaget. Opplegget omfatter informasjonsmøter og leseveiledningskurs fra faglig ansvarlige i kommunen. Hensikten med dette opplegget er å gå gjennom begreper fra lærebøkene som skal brukes når arbeidstakerne begynner på fagutdanningen og bevisstgjøre deltakerne om hva de faktisk kan. Det viser seg at mange arbeidstakere med lite utdanning kan langt mer enn de tror når de får en forståelse av begrepene. Dette leseveiledningskurset er viktig både for realkompetansevurderingen (arbeidstakerne kan mer enn de tror) og med hensyn til gjennomføring av opplæringens teoridel. Etter 4-5 måneder gjennomføres realkompetansevurderingen av faglærer fra videregående skole i kommunen. Faglærer inviterer arbeidstakere som skal realkompetansevurderes til en samtale - ordet "samtale" brukes tilsiktet fordi "realkompetansevurdering" er mer truende. Samarbeidet mellom kommune og fylkeskommune var avgjørende for at opplegget skulle fungere. Vurderingen følges opp av undervisningstilbud som varer et halvt år. Før deltakerne skal opp til fagprøven har de fagansvarlige en samtale med dem. 
En annen kommune utformet i samarbeid med fylkeskommunen et tilrettelagt, individuelt utdanningsløp hvor nærhet og bruk av erfaringer fra arbeidsplassen er viktige ingredienser. For å kunne delta i utdanningsløpet må søkerne ha gjennomført realkompetansevurdering. Undervisningen er lagt til tre forskjellige arbeidsplasser i kommunen med 10 til 15 deltakere i hver gruppe. Fylkeskommunen (videregående skole) er ansvarlig for undervisningen, og det legges stor vekt på å gjøre den mest mulig case- og praksisrelatert.

\section{Rekruttering til realkompetansevurdering}

Kjennskap til ordningen er vesentlig for at ufaglærte i kommunene skal rekrutteres til vurdering. Omkring halvparten av medarbeiderne "har hørt om ordningen" men vet lite konkret, mens en tredel kjenner godt til ordningen. Kjennskapen til mulighet for realkompetansevurdering er minst i de yngste aldersgruppene (under 36 år), og best i gruppen 36-45 år. Våre resultater viser omtrent det samme som Vox (2006) bortsett fra at vi finner en stor gruppe (omtrent halvparten) som har en overfladisk kjennskap til ordningen. Andre undersøkelser peker også på at informasjon om ordningen er kritisk (Oxford Research, 2009).

Det varierer litt fra kommune til kommune hvordan de informerte om mulighetene for realkompetansevurdering. Enhetsleder eller nærmeste leder samt kollegaer synes å være en viktig informasjonskilde, disse ble nevnt oftest av våre respondenter. Ofte informerer personalansvarlige eller andre som jobber med kompetanseutvikling enhetslederne om aktuelle kurs eller utdanningstiltak. Flere av enhetslederne vi intervjuet hadde oversikt over hvem som er interesserte i videreutvikling og hadde også en formening om hvem som er egnet, og oppfordrer disse til å melde seg på. Samtidig er det ikke nødvendigvis slik at alle enhetsledere faktisk har oversikt over aktuelle medarbeidere for realkompetansevurdering. Oppslagstavler, medarbeidersamtaler, tillitsvalgte og mer uformelle samtaler med leder ble også brukt som informasjonskanal. En kommune hadde for eksempel etablert en strukturert fremgangsmåte for prosessen fra ufaglært til faglært, og første ledd i denne prosessen er nettopp informasjon om mulighetene.

\section{Tilbud om realkompetansevurdering}

Initiativ fra den kommunale arbeidsgiver er et viktig ledd i tilretteleggingen. Tabell 2 viser hvor stor andel av respondentene som har fått tilbud om, ønsker eller har gjennomført en realkompetansevurdering. Disse alternativene ikke er helt gjensidig utelukkende, men de fleste respondentene har tolket det slik. Bare 14 $\%$ av hele utvalget svarer nei på alt: de har ikke gjennomgått, ønsker ikke å gjennomgå og har heller ikke fått tilbud. Av de som ikke har gjennomført en vurdering, svarer over halvparten at de ønsker en vurdering. Uten at det er et helt klart mønster, ser det ut til at de med minst utdanning får mest tilbud (noe som nok skyldes at dette er den sentrale målgruppen for realkompetansevurdering). Til 
sammenligning viste en undersøkelse i 2003 (Engesbak mfl., 2003) at $30 \%$ (av respondentene med lite utdanning) var svært lite interessert i realkompetansevurdering, mens de øvrige fordelte seg fra "litt" til "svært interessert", hvorav en firedel viste en relativt stor interesse.

Tabell 2. Gjennomføring av realkompetansevurdering, $\% .{ }^{a}$

Jeg har du fått tilbud om realkompetansevurdering fra kommunen (arbeidsgiver)

Jeg har gjennomgått en realkompetansevurdering.

Jeg ønsker å gjennomgå en realkompetansevurdering.

a Flere alternativer mulig.

$\mathrm{N}=213$

\section{Initiativ til vurdering}

Initiativ til å sette $\mathrm{i}$ gang med etter- og videreutdanning er ofte overlatt til den enkelte arbeidstaker i kommunen. Vel halvparten av kommunene viste seg behjelpelige med informasjon om realkompetansevurdering, en knapp tredel opplyste at de ga permisjon i forbindelse med vurdering, en av ti kommuner opplyste at ga støtte til reise og en av ti kommuner deltok i samarbeid som omfattet realkompetansevurdering (Helgesen, Stigen \& Tjerbo, 2009). Tabell 3 viser hvem som tok initiativ til at medarbeideren skulle få vurdert sin realkompetanse og vi ser at det hovedsakelig var medarbeideren selv, i tillegg har lederne vært viktige pådrivere. For medarbeidere på deltid var det i noe større grad arbeidsgiveren.

Tabell 3. Initiativ til realkompetansevurdering, etter stillingsbrøk, \% .a

\begin{tabular}{llll}
\hline & & \multicolumn{2}{l}{ Stillingsbrøk } \\
\cline { 3 - 4 } Hvem tok initiativ & Totalt & Deltid & Full tid \\
\hline Arbeidstakeren selv & 57 & 54 & 63 \\
Tillitsvalgt/fagforening & 2 & 1 & 4 \\
Nærmeste leder el enhetsleder & 27 & 31 & 20 \\
Kommunens personalkontor & 9 & 12 & 4 \\
Andre & 4 & 1 & 9 \\
\hline I alt \% & 100 & 100 & 100 \\
I alt N & 127 & 81 & 46 \\
\hline
\end{tabular}

a Gjelder bare respondenter som hadde gjennomgått eller skulle gjennomgå en vurdering. $\mathrm{p}=0,057$ (kji-kvadrattest for sammenheng mellom stillingsbrøk og hvem som tok initiativ)

Arbeidstakere mellom 36 og 55 år var særlig ivrige, mens arbeidstakere over 56 år i minst grad tok initiativet selv. For arbeidstakere uten utdanning utover grunnskole ser lederen/arbeidsgiveren ut til å være særlig viktig, mens for ar- 
beidstakere med annet morsmål var leder eller personalkontor oftere initiativtakere. Fremmedspråklige arbeidstakere ser også ut til å ha litt mindre kjennskap til ordningen, blant disse er det også en større andel som jobber deltid. Dette kan bety at både språkbarrierer og en svakere tilknytning til arbeidsplassen kan medføre at fremmedspråklige i mindre grad får relevant informasjon og i større grad er avhengig av informasjon og initiativ fra leder/arbeidsgivers side. Det samme gjelder langt på vei medarbeidere uten utdanning utover grunnskole. Dette betyr etter alt å dømme at arbeidsgiveren (representert ved nærmeste leder eller det sentrale personalkontoret) er den mest effektive måten å nå fram til minoritetsspråklige samt grupper med lite utdanning. For medarbeidere som er lite informert eller ikke tar initiativ selv er det dermed mye som tyder på nærmeste leder er en nøkkelperson for gjennomføring av systematisk arbeid med realkompetansevurdering. Dette taler for at målrettet arbeid med realkompetansevurdering bør bruke disse kanalene på en systematisk måte, blant for å hindre at viktige målgrupper faller utenfor.

\section{Nytte av realkompetansevurdering}

Dokumentasjon av realkompetanse er spesielt viktig for personer som mangler formell kompetanse i form av fagutdanning eller akademisk utdanning. Verdien av erfaring og opplæring for arbeidstakeren avhenger av i hvilken grad kompetanse blir anerkjent og verdsatt av både nåværende og fremtidige arbeidsgivere (Døving, Ure, Tobiassen \& Lund, 2005). Dokumentasjonen er særlig relevant med sikte på videreutdanning til fagbrev, samt for å dokumentere kompetanseelementer som er anvendelig $i$ andre jobber og eventuelt $i$ andre virksomheter (Døving mfl., 2005). Ved å dokumentere kompetanseelementer som også er anvendelig $i$ andre jobber og eventuelt $i$ andre virksomheter, styrkes arbeidstakerens stilling både i det interne og eksterne arbeidsmarkedet. Realkompetansevurdering med hensyn til læreplaner i videregående skole gir mulighet til å oppnå fagbrev. Dermed kan veien til fagbrev bli kortere, noe som kan være vesentlig for arbeidstakere som kanskje er lite motiverte i utgangspunktet (Døving \& Tobiassen, 2006).

De aller fleste (88 \%) som i vår undersøkelse hadde gjennomgått en realkompetansevurdering opplevde den som "nokså" eller "svært" rettferdig, bare 12 \% opplevde den som urettferdig. Det store flertallet var totalt sett "fornøyd" med vurderingen. Minoritetsspråklige opplevde realkompetansevurderingen som noe mindre rettferdig enn arbeidstakere med norsk som morsmål, og de var litt mindre fornøyd enn personer med norsk morsmål. Også deltidsansatte opplevde vurderingen som mindre rettferdig enn fulltidsansatte. Dette er viktige funn, men på grunnlag av disse dataene er det vanskelig å si noe om hva det skyldes. Det kan for eksempel tenkes at språkbarrierer gjør at fremmedspråklige kommer 
dårligere ut i vurderingen. Det kan også skyldes at formålet med realkompetansevurderingen ikke er klart kommunisert, slik at denne feilaktig kan oppfattes som en generell vurdering og ikke som en vurdering for et bestemt fag.

Våre respondenter oppfatter realkompetansevurdering først og fremst som et trinn på veien til fagbrev, men en god del legger også vekt på dokumentasjonen i seg selv. Arbeidstakerne i dette utvalget vektlegger altså selve dokumentasjonen mer enn bruk av dokumentasjonen i det eksterne arbeidsmarkedet. Selv om dokumentasjon og opplæring i prinsippet øker arbeidstakernes mobilitet i det eksterne arbeidsmarkedet, viser vår undersøkelse at arbeidstakerne i liten grad har tanker om å forlate arbeidsplassen. Det er altså en relativt liten risiko for kommunen å bistå ansatte med dokumentasjon av realkompetanse og videre kompetanseheving til fagbrev. Tallene gir i seg selv ingen forklaring på hvorfor, men en grunn kan være at medarbeidere med lite eller ingen formell fagutdanning kan oppleve det som en fin anerkjennelse av og bekreftelse på erfaring og kompetanse de sitter inne med. Til sammenligning påpeker Hagen og Skule (2004) at muligheten for å gjøre en bedre jobb og personlig interesse (ønske om personlig utvikling) samt høyere lønn fremstår som viktige drivkrefter for å ta formell videreutdanning innenfor kommunesektoren.

\section{Konklusjon}

Realkompetansevurdering betyr at arbeidstakeren får kompetanse opparbeidet gjennom praksis og erfaring anerkjent og dokumentert. Slik realkompetansevurdering gjør veien til fagbrev eller studiekompetanse kortere. For ufaglærte arbeidstakere med lang erfaring vil en slik anerkjennelse av realkompetanse styrke selvtilliten. I Norge har arbeidstakere over 25 år og uten videregående utdanning rett til vurdering.

Resultatene viser at ulike kategorier arbeidstakere står overfor ulike utfordringer. Vi har for eksempel sett at minoritetsspråklige skiller seg ut blant annet ved at de i mindre grad opplever realkompetansevurderingen som rettferdig og ved at de rapporterer om mindre gevinst av fagopplæring. Dette innebærer at arbeidsgiverens tilrettelegging så langt som mulig bør tilpasses den aktuelle målgruppen. For minoritetsspråklige kan leseveiledning som forberedelse til realkompetansevurdering og fagopplæring sees i sammenheng med opplæring i norsk og generell orientering om regler, begrepsbruk og norsk forvaltning innenfor fagopplæring.

Våre undersøkelser avdekket at arbeidstakere som ikke har norsk som morsmål skiller seg ut på flere måter, blant annet at de i større grad baserer seg på informasjon og initiativ fra leder eller personalkontor. Dette taler for å bruke disse kanalene på en målrettet måte for å fange opp minoritetsspråklige som kanskje ikke får informasjon fra andre kilder eller selv tar initiativ til realkompetansevurdering. Kompetansepolitikk overfor innvandrere og minoritetsspråklige 
medfører dermed særskilte utfordringer. Innvandrere og minoritetsspråklige er ingen ensartet gruppe og våre resultater sier lite om årsakene til at denne gruppen skiller seg ut.

Kommunen som arbeidsgiver kan spille en viktig rolle med hensyn til å informere ansatte om muligheten for realkompetansevurdering, ikke minst fordi en stor del av målgruppen ikke har særlig kjennskap til ordningen. Våre resultater tyder på at noe mer informasjon har nådd fram til målgruppen i de deltakende kommunene enn i den generelle befolkningen. Samtidig kan det tyde på at det fortsatt er rom for bedre informasjonsarbeid fra fylkeskommunen som har det overordnete ansvaret både overfor målgruppen og overfor kommunale arbeidsgivere som er lite kjent med ordningen. Bare en tredel av våre respondenter sier de har god kjennskap til ordningen og en firedel har ingen kjennskap. Når vi samtidig ser at det som oftest er arbeidstakeren selv (eller nærmeste leder) som tar initiativet, betyr det at tilstrekkelig informasjon til alle i målgruppen kan være nødvendig for å utløse initiativ. En daglig leder har mange oppgaver og mange medarbeidere, og selv om lederen er en god informasjonskanal kan den også bli overbelastet og det kan være mer effektivt å informere fra kommunen sentralt. Det er tendenser til forskjeller i hvordan den enkelte fylkeskommune forvalter regelverket for realkompetansevurdering og hvordan den enkelte arbeidstaker blir vurdert.

Realkompetansevurdering og mulighetene for fagutdanning kan være en viktig kilde for kommuner til å skaffe seg kompetent arbeidskraft. For kommunale arbeidsgivere kan oppgradering av assistenter til fagarbeidere være en enkel og billig tilgang til kvalifisert arbeidskraft. Et annet fortrinn er at de allerede kjenner de ansatte godt, og vet om dette er kandidater som er interessert og motivert for jobben sin. Noen kommuner skiller seg ut i systematisk tilrettelegging ved at de i samarbeid med de respektive fylkeskommuner, har utviklet klare rutiner for hvordan de skal gjennomføre systematisk realkompetansevurdering. De relativt store kommunene er dessuten i stand til å opprettholde et kontinuerlig tilbud.

For noen kan realkompetansevurderingen i seg selv oppleves som en slags eksamen, og de kan dermed være nervøse for hva dette innebærer. Informasjonsmøter hvor det også stiller representanter fra den videregående skolen, og gjerne også fra andre instanser i fylket ser ut til å fungere godt. Kommunene kan dermed ha mye å hente på å samarbeide tettere med fylkeskommunene når det gjelder informasjon. Jo bedre informert medarbeiderne er, desto mindre usikre vil de være om hva de går til. Mange med lite utdanning har liten tro på egen mestring knyttet til videreutdanning og blir ofte positivt overrasket ved å få bekreftet hva de kan og får styrket selvtillit som resultat av realkompetansevurdering.

Dersom ansatte oppfordres til realkompetansevurdering fra sin arbeidsgiver, vil medarbeiderne få en forventning om at dette skal resultere i noe mer, det være seg opplæring, høyere lønn, avansement, nye oppgaver eller større ansvar. Det tilsier at kommunen som arbeidsgiver bør ha en plan med hva realkompetanse- 
vurdering skal brukes til, hvis ikke kan det i verste fall resultere i mindre motiverte ansatte. For kommunene inngår realkompetansevurdering ofte først og fremst som et ledd i en større plan om å løfte arbeidstakere frem til fagbrev. I den forbindelse er det derfor vesentlig å kommunisere formålet med realkompetansevurdering. For det første å klargjøre at realkompetansevurderingen gjøres i forhold til kravene i en bestemt fagutdanning, og at formålet ikke er en bred kartlegging i virksomheten eller en total kompetanseoversikt for arbeidstakeren. For det andre bør arbeidsgiveren klargjøre hva arbeidstakeren kan forvente som oppfølging etter vurderingen. I et helhetlig opplegg bør realkompetansevurderingen inngå i et planlagt løp der arbeidsgiverens bidrag til hvert ledd er klargjort og avtalt. Selv om arbeidsgiver ikke lover et helhetlig tilrettelagt løp for den enkelte, bør ansatte informeres om hvilke muligheter som åpner seg og hvordan løpet videre vil være.

\section{Om forfatterne}

Erik Døving er førsteamanuensis ved Handelshøyskolen ved OsloMet. Han forsker blant annet på personalledelse, læring i arbeidslivet og ledelse av profesjonsutøvere.

Anita E. Tobiassen er førsteamanuensis ved Handelshøyskolen ved OsloMet. Hun forsker blant annet på internasjonalisering av oppstartbedrifter og små og mellomstore bedrifter. 


\section{Referanser}

Albrecht, J., van den Berg, G.J. \& Vroman, S. (2005). The knowledge lift: The Swedish adult education program that aimed to eliminate low worker skill levels, Discussion paper no 1503, Bonn: IZA - Institute for the study of labour.

Døving, E. \& Tobiassen, A.E. (2006). Arbeidsrelatert opplæring. Beta, 20(2), 147160.

Døving, E., Ure, O.B., Tobiassen, A.E. \& Lund, M. (2005). Evaluering av Kompetanseutviklingsprogrammet. Underveisrapport. SNF-arbeidsnotat nr. 55/05, Fafonotat 2005:25. Bergen: Samfunns- og næringslivsforskning.

Engesbak, H., Haugerud, V., Røstad, S. \& Stubbe T.A. (2003). ...men hvor skal vi henvende oss? Voksnes rett til grunnskole og videregående opplæring. Oslo/Trondheim: Vox, nasjonalt fagorgan for kompetansepolitikk.

Falch, T. (2011). Videregående opplæring og arbeidsmarkedstilknytning for unge voksne, Tidsskrift for Velferdsforskning, 14(11), 25-37.

Hagen, A. \& Skule, S. (2004). Det norske kompetansemarkedet - en oversikt og analyse. Fafo-rapport 461. Oslo: Fafo.

Haugerud, V., Røstad, S. \& Stubbe T.A. (2004). Intensjoner og realiteter: Fylkeskommunenes håndtering av voksnes rett til videregående opplæring. Oslo: Vox, nasjonalt fagorgan for kompetansepolitikk.

Helgesen, M.K., Stigen, I.M. \& Tjerbo, T. (2009). Kompetanseløftet 2015 - kommunenes deltakelse. Notat 2009-103. Oslo: NIBR.

Hermansen, Å. (2011). Personell og yrkesfordeling innen pleie- og omsorgssektoren. Fafo-notat 2011:13. Oslo: Fafo.

Hilleren, I., Haugøy, G., Fossan-Waage, T. \& Brekke, Ø. (2004). Læring i arbeidslivet, innovasjon og digital kompetanse. Resultater fra Vox-barometeret høsten 2004. Oslo: Vox, nasjonalt fagorgan for kompetansepolitikk.

Høst, H., Arnesen, C.Å., Næss, T. \& Aamodt, P.O. (2009). Evaluering av Kompetanseløftet 2015. Underveisrapport 1: Mars 2009. Rapport 12/2009. Oslo: Nifu-Step.

Hult, A. \& Andersson, P. (2008). Validation in the Nordic countries: Policy and practice. Aarhus: Nordisk nettverk for voksnes læring/Kristianstad: Fiora förlag.

Meld. St. 13. (2011-2012). Utdanning for velferd: Samspill i praksis. Melding til Stortinget. Oslo: Kunnskapsdepartementet.

Nordhaug, O., Døving, E. \& Nordhaug, I.W. (2004). Kompetanse i norske bedrifter: Verdiskaping, drivkrefter og behov. Søkelys på arbeidsmarkedet, 21(1), 101113.

Oxford Research. (2009). Med blikket rettet fremover: Sluttrapport for evaluering av realkompetansevurderingsprosjektet innenfor Kriminalomsorgen. Kristiansand: Oxford Research.

Randall, D.M. (1990). The consequences of organizational commitment: Methodological investigation. Journal of Organizational Behavior, 11, 361-378. 
Røstad, S. \& Storli, R. (2006). Realkompetanse i praksis - en casestudie om kompetanse fra arbeidslivet og tredje sector, og forholdet mellom godkjent realkompetanse og opplæringstilbud. Oslo: Vox, nasjonalt fagorgan for kompetansepolitikk.

Sosial- og helsedirektoratet. (2006). Rekruttering for betre kvalitet. Rapport nr. 3 fra Rekrutteringsplan for helse- og sosialpersonell 2003-2006, IS-1411, Oslo: Sosial- og helsedirektoratet.

SSB. (2018). Innvandrerne sto for 1 av 6 årsverk innen omsorg. Oslo: Statistisk sentralbyrå. Hentet 29 september 2020 fra https:/ / www.ssb.no/helse/artikler-ogpublikasjoner/innvandrerne-sto-for-1-av-6-arsverk-innen-omsorg

Stortingsmelding nr. 42. (1997-98). Kompetansereformen. Oslo: Kirke-, utdanningsog forskningsdepartementet.

Utdanningsdirektoratet. (2008). Voksnes rett til videregående opplæring. Rundskriv datert 2. september 2008. Oslo: Utdanningsdirektoratet.

Utdanningsdirektoratet. (2014). Nasjonale retningslinjer for realkompetansevurdering av voksne i videregående opplæring. Oslo: Utdanningsdirektoratet.

Vox. (2006). Voksnes læring 2006 - tilstand, utfordringer og anbefalinger. Basis! Oslo: Vox, nasjonalt fagorgan for kompetansepolitikk.

Vox. (2007). Rett og rimelig. Felles forståelse og praktisering av voksnes rett til videregående opplæring. Oslo: Vox, nasjonalt fagorgan for kompetansepolitikk.

Vox. (2011). Realkompetansevurderinger - status og utfordringer 2011. Oslo: Vox, nasjonalt fagorgan for kompetansepolitikk.

Vox. (2012). Vox-speilet 2012. Voksnes deltakelse i opplæring. Oslo: Vox, nasjonalt fagorgan for kompetansepolitikk.

Vox. (2013). Vox-spegelen 2013. Vaksne si deltaking i opplæring. Oslo: Vox, nasjonalt fagorgan for kompetansepolitikk. 